\title{
Aoristo)))))
}

International Journal of Phenomenology, Hermeneutics and Metaphysics

\section{Sobre o Cansaço}

\author{
About Tíredness \\ Profa. Dra. Marcía Sá Cavalcante Schuback \\ Södertörn University - Estocolmo'
}

\section{RESUMO}

O presente artigo propõe um esboço para uma fenomenologia do cansaço e do cansaço próprio à convalescência de uma doença, evocando a tradição médica grega de Asclépio e alguns aspectos da noção nietzschiana de convalescência (Genesung). Com base nessa descrição, discute o cansaço do homem contemporâneo, num mundo que exaure a vida não permitindo que a vida se canse e repouse. Esse texto foi escrito com base num diálogo não escrito com Frei Hermógenes Harada.

\section{PALAVRAS-CHAVE}

Cansaço; Convalescência; Doença; Asclépio; Nietzsche

\section{ABSTRACT}

The present article proposes a sketch to a phenomenology of exhaustion and the exhaustion and being-tired inherent to a disease, evoking the medical tradition in ancient Greece and some aspects of Nietzsche's concept of convalescence (Genesung). Based on this description, the text discusses the being tired of contemporary man in a world that exhausts all life not letting life get tired and rest. This was written based on a non-written dialogue with Pater Hermógenes Harada.

\section{KEYWORDS}

Tiredness; Convalescence; Disease; Asclepius; Nietzsche

\section{INTRODUÇÃO}

Minha intenção era escrever um texto sobre a "providência divina", com base em algumas das cartas preciosas que Frei Hermógenes Harada me enviou há muitos anos atrás e que guardo comigo juntamente com outros de seus escritos. Infelizmente, por causa da pandemia, fiquei presa no Rio de Janeiro, sem poder voltar para casa na Suécia e reler as cartas. Lembro-me que, em algum momento

\footnotetext{
${ }^{1}$ E-mail: marcia.cavalcante@sh.se.
} 


\section{Aoristo)))))}

International Journal of Phenomenology, Hermeneutics and Metaphysics

dessa nossa conversa, discutimos a questão do "destino" do Ocidente e do "cansaço" do homem europeu e da metafísica ocidental. Esse tema está presente em vários escritos de Husserl ao tematizar a questão da Europa e da Crise das ciências europeias. Lembro-me também de Frei Hermógenes dizer que, para realmente compreender o sentido do cansaço europeu e da filosofia, era preciso, pensar o cansaço, descrevê-lo, ouvir o que o cansaço nos diz, antes de nos cansarmos ao ler tudo que já se escreveu sobre o cansaço metafísico. Talvez esse estranho tempo de pandemia seja uma hora propícia para escutar o que o cansaço nos diz. Pois parece que uma das experiências gritantes hoje é a do cansaço: cansaço do sistema do mundo, cansaço das injustiças alarmantes, da sandice política, mas também cansaço do esgotamento do mundo e da natureza, cansaço de ser e existir. Sem poder acessar minhas anotações, as cartas e os escritos de Frei Hermógenes, que não se encontram em sua página, proponho esboçar algumas notas sobre o cansaço, sem nenhuma pretensão de esgotar o assunto, sem querer cansar o cansaço. Mas escrevo como conversava e sempre ainda converso com ele.

1

Os gregos tinham, como sabemos, seus mitos e seus deuses. Nós, modernos, temos as nossas mitologias e histórias para recorrer, mas também uma história doente de história, sobrecarregada de memória e culpa. O que os mitos gregos nos contam sobre deuses são hoje reminiscências da infância dos tempos, de fantasias fabulosas, que eventualmente dão colo, mas provavelmente não explicam nossa história ferida e cansada. Mas, talvez não se deva ouvir esses mitos a não ser para somente escutar uma estória que vem de um longe, de um longe bem longe, próprio ao ser da palavra.

Há um mito grego que conta de um deus que era médico. Seu nome era Asclépio. É difícil para nós hoje entendermos o que significa um deus também ser um médico, o que não é o mesmo que tomar um médico por deus. Em Epidauro, onde havia muitos outros templos, construiu-se o maior templo medicinal na Grécia dedicado a Asclépio. Era um hábito frequente levar os gravemente enfermos para lugares secretos e protegidos dentro de diferentes templos, que não poderiam ser trespassados por qualquer um e para onde somente os consagrados podiam levar os doentes. Esses lugares secretos no templo chamavam-se adyton, isto é, lugar inacessível. Não era uma casa para doentes, mas um templo-lugar para os que estavam se curando, um lugar onde doenças sob a proteção do deus-médico Asclépio podiam ser conduzidas de volta à saúde, a dor à alegria, a morte à vida. Nos mitos havia uma compreensão geral da doença que parece estranho para nós hoje, isto é, que a doença é a vida que levada para longe de si mesma.

Como uma arte curativa, a arte medicinal era considerada sagrada, pois era a arte de levar o doente que havia se distanciado da vida de volta não para a vida, mas para a vida da vida, para a totalidade da vida. Sagrada era, portanto, a arte de distanciar essa distância - i.e. a doença - da vida, de pôr à distância essa distância da vida que é a doença. Nesse sentido é na própria doença que está o curar. A arte divina de Asclépio pode ser interpretada como uma introspecção profunda nas 


\section{Aoristo)))))}

International Journal of Phenomenology, Hermeneutics and Metaphysics

diferentes maneiras de a vida ser levada para longe dela e dela se aproximar. Ele viu que a vida talvez não fosse mais nada do que ser levada para longe e ser trazida para perto, um ficar à distância e voltar à proximidade da vida. Mas não só a doença era considerada uma maneira da vida ser levada para longe de si. O sono, os sonhos, as meditações e a embriaguez extáticas também eram diversos modos de mostrar as variadas maneiras da vida ser levada para longe e ser trazida para perto. Como vida levada para longe da vida pela vida, o sono é o irmão da morte, como dizem as palavras proverbiais de Homero. Na sua arte curativa e sagrada, Asclépio levava a vida doente de volta para a totalidade da vida ao levar o doente para um sono longo, a chamada incubação. Asclépio não inventou apenas a terapia do sono e do sonho, mas também outras maneiras de meditar como terapia e a sua célebre nooterapia, a cura pela mente. Os doentes adormeciam no sono, sonhavam sonhos, pensavam pensamentos para, na fraqueza própria da vida, buscar a vida que restava e a força para afastar a vida do afastamento da vida que é a doença. Para Asclépio e seus seguidores, ou seja, os que praticavam a arte curativa desse deus, a doença era primeiramente o cansaço da vida, a vida cansada da vida.

Tudo que vive se cansa - homens, animais, a terra e o mundo. Por isso, os cansados têm que estar deitados ou se deitarem. O verbo grego para dormir é katheudo que significa deitar-se, uma palavra que também significa o pôr do sol e da lua. Em muitas línguas diz-se que se cai no sono ou que se cai de cansaço. Tudo que vive e se mexe em e por si mesmo - i.e. tudo que se afasta e é levado para longe - se cansa, precisa descansar e se deitar. Nesse sentido, o cansaço e a doença se relacionam da mesma maneira que vida e morte.

O cansaço interrompe o curso da vida. O cansaço é como um romper da vida. Tira o que vive da sua direção, leva para outro lugar, o desloca. O cansaço é como uma vida deslocada. Que os doentes eram levados para um lugar escondido no meio do templo - que é o lugar do segredo - testemunha a força deslocadora do cansaço. Não era para separar os doentes dos saudáveis, os que vivem dos que estão mortos, mas justamente para demorar-se e habitar durante um tempo o limiar entre um e outro. A doença, i.e., o cansaço da vida é uma experiência de limiar. Aqui está a luz da noite que amarra as contradições em vez de separá-las e que mostra os pontos de contato e virada em vez dos contrastes e linhas de separação. Esses antigos deslocamentos dos doentes tinham como propósito deixar a doença mostrar os pontos onde vida e morte, doença e saúde, fraqueza e força, cansaço e ânimo eram inseparáveis. Des-locar significa aqui, nesses mitos, juntar contradições.

A doença é um cansaço da vida, mas não dá para negar que o cansaço causa doenças e que doenças também cansam e extenuam. Depois de um dia de trabalho é preciso descansar assim como depois de um parto deve-se fazer resguardo. Depois de uma doença é preciso recuperar-se. No mito, Asclépio curava não apenas junto com a sua esposa Epione - a aliviadora - mas também com as filhas Higieia, a deusa da saúde, Panakéia, a deusa das ervas medicinais, Aglea, a deusa do embelezamento e a filha Iaso, a deusa de recuperação. De Iaso sabemos muito pouco. A palavra Iaso, significa em grego antigo aquecer e cuidar, reviver e encorajar. A recuperação é o 


\section{Aoristo)))))}

International Journal of Phenomenology, Hermeneutics and Metaphysics

maior segredo em relação à saúde e à doença porque se trata do mais opaco, que é a relação entre doença e saúde. A deusa da recuperação é quem leva o doente, o cansado da vida, de volta para a vida, o mundo de volta para o mundo. Na verdade, ninguém fica doente; é a vida que se enfraquece e se cansa neste alguém. A arte de Iasos era a arte de cuidar do cansaço da vida, da vida que permanece na doença.

Nietzsche escreveu em Assim falou Zaratustra sobre a convalescência, a recuperação. Ele descreveu a recuperação de Zaratustra como a recuperação da vida, pois Zaratustra não era um ser humano que vive porque pensa, mas a vida que vive e pensa dentro do ser humano. Zaratustra é a cena onde a vida do tempo e o tempo da vida acontecem. Num episódio do livro, Nietzsche conta como Zaratustra, i.e., a vida na vida de um ser humano, um dia se cansa e fica deitado sem querer comer nem beber. Zaratustra não podia mais procurar a vida. Era a própria vida que constantemente o procurava "...seus animais não o abandonavam nem de dia e nem de noite e todos ficavam deitados ao seu redor". (NIETZSCHE, 2012, p. 208) Enquanto os animais da vida estavam do lado do Zaratustra deitado, cansado e doente, "exceto a águia quando voou para buscar alimento e o que ela apanhou e saqueou, pôs sobre o leito de Zaratustra: de modo que afinal Zaratustra se achou deitado entre frutinhas amarelas e vermelhas, uvas, jambos, pinhas e folhas de cheiro. E a seus pés havia dois cordeiros, que a águia havia penosamente arrebatado a seus pastores". (NIETZSCHE, 2012, p. 208) Nietzsche descreve a convalescência ou recuperação como um modo de como o doente cansado se segura no cansaço e neste é aquecido pela própria vida. Isto lembra antigas tradições entre alguns índios brasileiros, por exemplo, de deixar o doente descansar ao lado de um caranguejo vermelho para que a força curadora da cor vermelha faça a doença retrair-se. Ou entre monjas medievais, como Hildegard von Bingen, que dependendo das doenças colocavam diferentes pedras ao lado do doente, como p. ex. a ágata para os que sofriam de problemas no fígado. À recuperação pertence a arte de escutar como "o mundo espera por ti como um jardim", (NIETZSCHE, 2012, p. 208) os animais diziam para Zaratustra. E isto de uma maneira tal que se torne possível atentar como "a cada alma corresponde outro mundo; para cada alma, cada outra alma é um mundo por trás." (NIETZSCHE, 2012, p. 208) Algo parecido encontramos na escultura de Wilhelm Mundt em frente ao hospício de Estocolmo. 


\section{Aoristo)))))}

International Journal of Phenomenology, Hermeneutics and Metaphysics

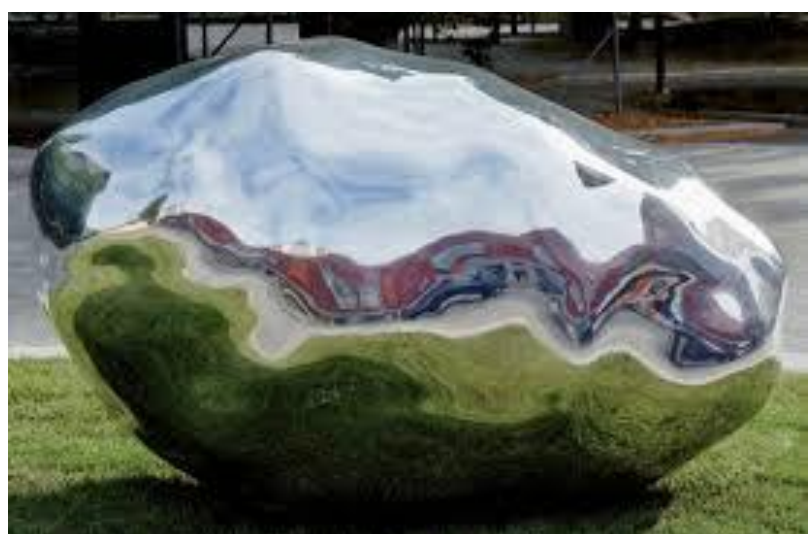

MUNDT, Wilhelm. Trashstone 569, (2013), Stockholms Sjukhem, Foto: Ake E: son Lindman

É uma pedra que é um animal, uma "pedranimal", poderíamos dizer, um animal sem nome, sob uma árvore. Se lemos bem Nietzsche e ouvimos tradições antigas e imemoriais, como as africanas, indígenas e asiáticas e lentamente observamos a pedra posta-fora de Mundt é possível ver que a recuperação é um tempo onde o cansaço atenta para a maneira da vida e do mundo agirem como um ritmo de ser e não-ser. Mundt chamava essas suas pedras de Trashstones, pedras de lixo, pedras postas fora, jogadas pra lá e pra cá, de vez em quando, como meteoros caídos de tempos insuspeitados. Não têm nomes, apenas números. Não significam nada. São o que são, vidas singulares sem porquê e onde o sentido não é nada mais do que seu abismo. A vida singular, com seu apenas-aqui, apenas-assim, somenteassim, somente-então, são vidas com conteúdo e energia secretas. Vidas inconcebíveis como folhas que o vento leva ou como um caroço cuspido. Tanto quanto as montanhas erodidas dos movimentos lentos do vento e do esquecimento, Mundt pole suas pedras como se quisesse mostrar como elas, sem nome e sem porque, refletem a maneira de a vida ser sempre uma vida única. As pedras de Mundt nos lembram os diferentes lances de dado da vida.

\section{2}

Esses antigos mitos e deuses gregos parecem estar tão longe da nossa sociedade cansada, essa que não se cansa de instrumentalizar e comercializar cada vez mais tanto a vida como a morte. Esses templos medicinais de há muito já desapareceram das nossas estórias e foram substituídos por lugares onde os doentes são separados dos saudáveis, os que estão morrendo dos que estão vivendo e onde o cansaço é encoberto e iludido com diferentes técnicas de "wellness" e "work-out". Os hospitais mais antigos na Europa eram chamados de lazareto, uma palavra que unia Nazaré, o nome da ilha italiana onde se levavam os leprosos, e Lázaro, o morto a quem Jesus devolveu a vida. Eram lazaretos porque isolavam os doentes e os moribundos, impedindo assim a vida de tocar na morte. O que esses hospitais queriam impedir era justamente o contato entre vida e morte, este que Asclépio descobriu entre sono e vigília, exaustão e ânimo. Contato passou então a ser chamado de contágio e um hospital virou internação onde o corpo tem que se separar da alma, não para viver, 


\section{Aoristo)))))}

International Journal of Phenomenology, Hermeneutics and Metaphysics

mas para sobreviver. Assim começou o lema da modernidade, que pode ser formulado como não viver para não morrer e o homo humanus foi substituído pelo "homo patologicus".

Sem essa visão da diferença entre corpo e alma, entre sono e vigília, entre saúde e doença, em suma, entre vida e morte, seria impossível construir a indústria e a maquinaria de vida e morte que hoje se espalha pelo planeta, ainda mais em tempos de pandemia. Numa sociedade onde os lucros com a vida e com a morte tem de se tornarem eles mesmos lucrativos, fica mais difícil entender o que se descreve como as experiências limiares dos mitos. "Ficamos pobres de experiências limiares" escreveu certa vez, Walter Benjamin, um grande pensador da nossa história tão ferida e doente do século XX, para indicar quão pobre é a nossa cobiçada riqueza. Pobre na experiência limiar é uma sociedade que não entende que a doença pode ser o cansaço da vida e que não dá espaço nem tempo para o cansaço.

A máquina incansável do mundo em que vivemos nos faz mais e mais doentes do que chamamos de estresse. Hoje palavra estresse é usada por cada um, sem tradução, mas com diferentes sotaques e com uma força desgastante. A palavra estresse registrou-se pela primeira vez cerca de 1850 com o significado de submeterse à violência ou à força e de ficar nessa condição. Em inglês, até ganhou o significado de "sublinhar algo". É quase como uma ironia inglesa de como a sociedade hoje sublinha, estressa, o estresse, "stresses on stress". Que a palavra surge tão tarde para designar um fenômeno tão antigo como o ser humano - isto é, a submissão à força e à violência - desperta a questão para que tipo de submissão está aqui em jogo. Em stressing the stress o $s$ é sublinhado, pois trata-se de se submeter a diferentes forças e violências, i.e., trata-se de uma submissão auto-infringida, autoescolhida e auto-motivada. Com um acento sem fôlego no s- o estresse da contemporaneidade - surge o caráter sinistro do sujeito moderno e pós-moderno, que é aquele de, ao querer controlar tudo com uma ganância incansável, tornar-se submisso e controlado pela sua própria vontade de controle. Se o sujeito moderno, autônomo e independente, se acha capaz de controlar tudo que tem dentro do seu horizonte, o sujeito pós-moderno é estressado por revelar-se como um sujeito regido por sua avidez controladora. Na condição entrópica que descreve nossa máquina mundial, o cansaço tornou-se incansável. Um cansaço incansável não é mais um cansaço, mas apenas um estresse. O ser humano incansavelmente cansado nesse mundo de reorganizações, reavaliações e reestruturações é um humano que não pode estar cansado e que não sabe mais que tudo que vive se cansa e que o cansaço é uma das muitas fontes secretas da vida.

3

Diferentes tentativas de no tempo e espaço criar quadros e um terreno para o cansaço corre o risco na sociedade hoje de serem exploradas por diferentes estratégias de exploração - de se transformarem num "empreendimento e empreendorismo" da vida e da morte, que ou bem só buscam lucros ou se esvaziam

Marcía Sá Cavalcante Schuback 


\section{Aoristo)))))}

International Journal of Phenomenology, Hermeneutics and Metaphysics

num sentimentalismo frívolo. Mas onde então encontrar um lugar para o cansaço? Talvez esse lugar e tempo seja algo diferente do que um terreno e um tempo, um tempo e um espaço, algo outro do que uma casa. Talvez esse lugar e tempo nada mais seja do que um gesto, um gesto de atenção, que como a pedra de Mundt sem nome olha para cada um sem precisar ser olhado. Pois o que é o cansaço a não ser a própria atenção aos movimentos mais lentos, aos atrasos ou adiamentos, às distrações ou disfunções? Não é o cansaço uma condição que força o corpo a notar os menores acontecimentos de transição, os pequenos adiamentos na vida que aparecem como o que está fora de ritmo consigo mesmo? O cansaço mostra finalmente que a atenção não é um movimento da distração para a concentração, mas bem mais um parar nos pontos de virada e momentos de deslocamentos. O cansaço presta atenção a como a parada é um quase-movimento, como o comprimento é um "quase" - quase aí, quase aqui, quase assim ou quase aquilo. Aqui, o coração bate forte para tudo que tem que ser feito. Qualquer passo pra frente ou para trás é dado como se o mundo inteiro estivesse em jogo. Mas talvez justamente isso seja o que o cansaço desvela: que o mundo e a vida inteira estão sempre em jogo sem que a vigília disso se dê conta. É preciso uma ex-haustão, um cansaço que coloca a vida ao lado de si mesma, que retira a vida de si mesma para atentar a como a vida é uma miríade de deslocamentos e atrasos, descentramentos e distanciamentos, contradições e tendências, não-mais e ainda-não, quase e ainda, mais ou menos e sem fundo. $O$ cansaço atenta para o desvanecimento da cor e a cor do desvanecimento, caídas e subidas quase despercebidas, como flores crescidas debaixo na terra e não ao contrário. E nesse inaudito trabalho da atenção - o cansaço - que deixa a alma do corpo cair pesada na terra, acontece às vezes de os olhos olharem para cima rumo ao céu, para o esquecido, apenas para descobrir como os pés estão ligados à terra. Ao mesmo tempo que o cansaço deixa aparecer um espectro infinito de variações mínimas, ele segura o corpo numa tensão dolorosa com a alma do corpo, uma tensão que deixa o corpo trancado em si mesmo - "quero mudar minha condição, mas não aguento", "quero andar, mas não consigo", "quero ir, mas não posso". O corpo está pesado demais para o peso do corpo. A virada - o ponto milagroso no qual a doença se recupera, no qual o cansaço descansa - é imprevisível. Acontece quando acontece, quando a vida infla o corpo pesado como se fosse um balão de ar quente ou uma folha que um vento súbito leva.

O que o cansaço atentou deixa seus vestígios no corpo da alma que fica mais e mais lento e lerdo, um pouco caído e inclinado para baixo, para resguardar o pequeno, recém-descoberto, distanciamento da terra e uma distância mais perto do céu. São medidas mínimas de gestos que quase nem dá para sentir nem escutar porque parecem traços de um bem longe-daqui das palavras que nos sobrevêm, como as palavras de mitos ancestrais.

\section{REFERÊNCIAS}

NIETZSCHE, F. W. O convalescente. In: Assim falou Zaratustra.Trad. Paulo César de Souza. São Paulo: Companhia das Letras, 2012. 


\section{Aoristo()))))}

International Journal of Phenomenology, Hermeneutics and Metaphysics

Submetido: 10 de janeiro de 2021

Aceito: 15 de janeiro de 2021

Marcia Sá Cavalcante Schuback Toledo, v. 4, n.1 (2021) p. 30 36 